FINAL.

LA-UR $-85-3176$

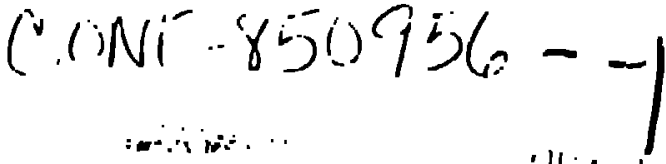

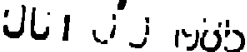

DE86 000781

TITLE A NEW HIGH-BRIGHTNESS ELECTRON INJECTOR FOR FREE-ELECTRON LASERS DRIVEN BY rf LINACS

AUTMORISI

J. S. Fraser. R. L. Sheffield and E. R. Gray

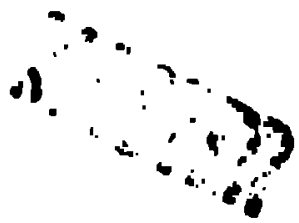

Seventh International Free Electron Laser Conference, Tahoe City, California, September 8-13, 1985

\title{
DIX '.AIMKR
}

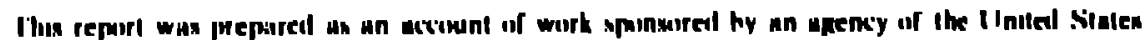

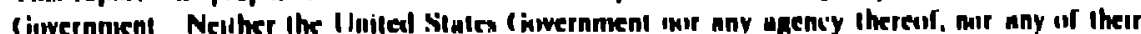

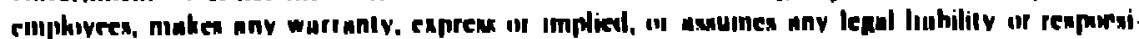

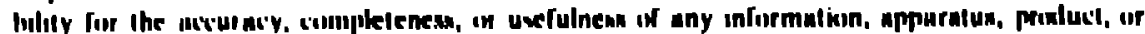

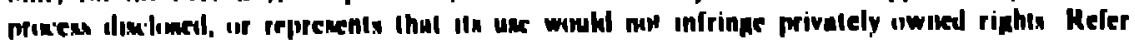

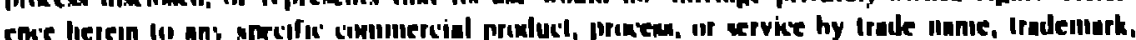

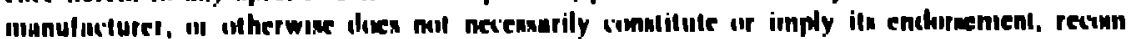

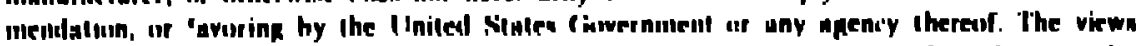

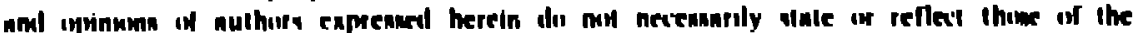

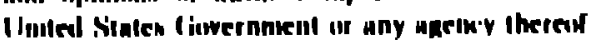


A NEW HIGH-BRIGHTNESS ELECTRON INJECTOR FOR TREE-ELECTRON LASERS

DRIVEN BY RF LINACS*

JOHN 5. FRASER, RICHARD L SHEFFIELD and EDWARD R. GRAY, AT-7, MS H825

Los Alamos National Laboratury. Los Alamos, New Mexico 87545

A free-electron laser oscillator, driven by an rf linac, requlres a traln of electron bunches fellvered to an undulator. The brightress requlrement exceeds that avallable from a conventional linac with rf bunchers. The demonstrated high brightness of laser-llluminated photoemltters indicates that the conventional buncher system might be eliminated entirely. thereby avoiding the usual large loss in brightness that occurs in bunchers. A photoemitter with a current density of about $200 \mathrm{~A} / \mathrm{cm}^{2}$ is placed on an end wall of an rf cavlty to accelerate a 60-ps bunch of electrons to $1 \mathrm{MeV}$ as rapidiy as posslble. Prellminary experimental work, simulation calculations, and discussions on emittance messurement technlques and positive lon motlon in the $r f$ gun are presented.

?. Introduction

A free-eiectron laser ( $F E L$ ) osclllator requires a trail of hlgh-denslty electror bunches passing through an undulator, a requirement that implles not only a high peak current (typlcally:100 A), but also a low transverse beam emittance. Radlo-frequency llnear accelerators ale well sultei to de'lver beams of low emittance, bunched to a small longitudinal phase wldh. However, if high peak-current bunches were located in every rf bucket, excessively high average beam powers would result. Therefore, a subharmonlc bunching (SHB) scheme is usually employed.

\footnotetext{
This work was performed under the ausplces of the US Uepartment of Energy and supported hy the BMD Advanced Technology Center.
} 
In rf-linac-driven FELs. conventional subharmonic bunchers are currently used, but the resulting dilution of phase space is not acceptable for advanced high-power and/or short-wavelength FELs. This paper describes an Injector development program, now under way at Los Alamos, based on the use of a laser-11luminated photocathode placed or: the end wall of an $\mathrm{rf}$ cavity. that is, an "rf gun" that eliminates the cunventional bunching process entirely.

2. Brightness of electron sources

The normalized peak brightriess of a beam is defined as

$$
B_{n}=I /\left(E_{x} E_{y}\right) \quad\left[A /\left(m^{2} \cdot r_{a d}^{2}\right)\right]
$$

where $I$ is the peak current and $E_{x}$ and $E_{y}$ are the normalized transverse phase-space areas (emittances) of the beam [1]. For a typlcal thermionic emitter at $1160 \mathrm{~K}$. the average transverse energy of the emitted electrons is $0.1 \mathrm{eV}$; corresponding normallzed peak br ghtness is $11 \mathrm{mlted}$ to $[2,3]$

$$
B_{n}-1 / E_{n}^{2}-4.1 \times 10^{9} \mathrm{~J} \quad\left[A /\left(\mathrm{m}^{2} \cdot \mathrm{rad}^{2}\right)\right]
$$

for a uniform current density J. The bunching and initlal acceleration process typlcally results in high peak currents. but a price is pald in the dliution of phase space in all six dimensions.

A normalized transverse electron beam emlttance of $E_{n}$ - Ya gives an optlcal gain in the whglel very close to the maximum [2], whereas $E_{n}-2$ ya reduces the galn by a factor of $4[2,3]$. Figure 1 shows the normallzed peak brightnes, for several typlcal single-bunch accelerators as well as results for two pulse traln accelerators (4-7). For comparison, the maxlmuin avallable brighelless from a photoemissive cathode is shown for a current Jensity of $200 \mathrm{~A} / \mathrm{cm}^{2}$. a current denslly that is well within the cathode's demonstrated capablllty $(8,4]$. The brlghtness requlrements for two llfferent wavelength fel osclllators are also shown. 
3. Electron bunch transport in an rf gun

The thermal energy of the electrons as they leave the surface of the photoemitter is low. However, the transient forces to which an intense bunch is subjected as it emerges intc a strong accelerating fleld are large and are comparable to the space-charge force.

Jones and Peter [10] have shown the importance of nonlinear forces in detalled simulation calculatiors of the transport of very short electron bunches in de and $r f$ flelds. Emitlance growth is minimized if at least twr. conditions are met: (1) the current density in the bunch is uniform and therefore the space-charge force is linear in the radial direction, and (2) the cavity fleld (In the absence of space charge) is radially llnear. The latter condition is satisfled if the cavity wall shace is given by

$$
\rho^{2}=2\left[(\psi-\zeta)(1-2 \mu)+\zeta^{3} / 3-\mu \zeta^{2}\right] /(\zeta-\mu) .
$$

where $p=r / z_{0}, \zeta-z / z_{0} \cdot \psi=-\Phi / E_{0} z_{0}$, and $\Phi$ is the electric potential: $E_{0}$ is the (axlal) electric fleld at the $\operatorname{origin}(r-0,2=0)$. The radial electrlc: fleld is given by $E_{p}=\rho(\zeta-\mu)$. The position at which the axlal electrlc fleid vanishes for $r=0$ is denoted by $z_{0}$, and $\mu$ is an arbltrary focusing parameter. For $0<\mu<0.5$, the radial electric fleld exerts a foclising force in the reglon $0<z<\mu z$

In a bunch of finlte length, the eluctrons in the leading-and tralling-edge reglons are acted upon by the large, nonlinear. translent. longltudinal forces arising from the large, rate of change in the total current, an action that leads to emlttance growith. Therefore, the emittance growth is reduced by using long pulses $! n$ whlch the hot end reglons form a smaller fraction of the whole. 
4. Design of photoemitter injec or

The high current density avallable from semiconductor photoemitters makes feasible the formation of high peak-current bunches without the loss of beam quality that accompanies the conventional bunching process. Current densitles of about $200 \mathrm{~A} / \mathrm{cm}^{2}$ have been reported $[B, 9]$ from laser-11luminated Gaks and $\mathrm{Cs}_{3} \mathrm{Sb}$. Furthermore, the average electron energy has been shown to be $0.1 \mathrm{eV}$ for low current densitles [11]. If the average transverse energy of the emitted electrons does not rise rapidy with current density, then the production of bunches with high peak brightness is indeed possible.

The temporal profile of the bunches can ise controlled to the same extent that the incident laser pulse can be tallored. Streak cameras with $\mathrm{Cs}_{3} \mathrm{Sb}$ photocathodes have picosecond time resolutions. Therefor', for a 50-ps laser pulse, the temporal proflle of the electron emission should follow the laser pulse without signiflcant brcadtilng. The radlal proflle of the electron current density also can bc controlled through the laser pulse.

Laser pulse wldths of about 60 ps w1ll be directed through the electron beam bore hole onto the photocathode. To accelerate the optlcally chopped electron bunches as rapldiy as posslble. the photoemitter is placed on the end wall of the first rf cavity in an infector linac, the rf gun cavity. The cavlty walls near the beam axls are shaped according to Eq. (1). The focusing parameter $\mu$ was chosen to be 0.15 , a value that glves minimur emittance growth $[10]$, and the scalling parameter $z_{0}=4.0 \mathrm{~cm}$ was used. The outer part of the $r f$ gun cavlty was shaped to maximlze the cavity quallty factor $Q$. Flgure 2 shows the rf gun cavlty dissigned for an operating frequency of $1300 \mathrm{MHz}$. Plots of the radlal electric field obtalned from the 
Code SUPERFISH are shown in fig. 3 for different $z$ values. They are, indeed, much more linear than the corresponding flelds in a more conventional rf cavity optimized for high shunt impedance. Flgure 4 shows the radial electric field in a high shunt impedance cavlty [7].

5. The 5-MeV injector linac

rollowing the initial acceleration in the rf gun cavity, the beam enters a second cavity that is rf powered and phased separately from the first or if gun cavity. Figure 5 is a schematic of a proposed photoem!tter injector. The septum separating the two cavitles is made as thin as possible so that the overall accelerating gradient is maximized. The proflle of the second and the following cavities is patterned after the same set of equipotentials as used in the design of the rf gun cavity. ihe midplane of these cavities is the $\zeta-\mu$ plane in which the radial electric field is zero. The bore radius $(1.7 \mathrm{~cm})$ is made larger than that in the rf gun cavity $(1.2 \mathrm{~cm})$ by using the $\psi=0.85$ surface. A larger bore was chosen to reduce the coupling to the dipole, beam-blowup modes. The ust of the smaller bore on the rf gun cavlty produces a couplling coefficlent between it and the second cavity of $10^{-4}$.

The cavities numbered? to 5 form a blperiodic structure operating in the $\pi / 2$ mode. The slde-coupling cavitles will be fixed at $90^{\circ}$ azlmuthal intervals along a splral and will he fabilcated from stalniess steel; both features tend to supprese the dipole modes.

The theoretical effective shunt Impedance of the side-coupled Inear-fleld cavlty chalri is $2 \mathrm{~T}^{2}$. $36 \mathrm{M} \Omega / \mathrm{m}$ as compared wlth the value $58 \mathrm{M} \Omega / \mathrm{m}$ for the optimlzed shunt Impedance cavity [7]. The addition of the slde-coupler slots and the Imperfectlons introduced by brazing. degrade the shunt Impedances to about 32 and $52 \mathrm{M} \Omega / \mathrm{m}$, respectively. 
Some degree of magnetic phase compression will be required to simultaneously satisfy the conflicting requirements of long pulses in the rf gun cavity (to minimize the end effects) and short pulses in the main accelerator (to $m \ln 1 \mathrm{~m} \mid z e$ energy spread). To this end. an energy-modulating cavity is added after the fifth accelerating cavity. The phase is shifted forward by $90^{\circ}$ from a normal accelerating field so that the gap voltage is rising and passing through zero when the center of the bunch is in the midplane of the cavity, a condition when the modulating cavity is $\lambda / 4$. $5 \lambda / 4$, etc., from the center of the last accelerating cavity. The A/4-spacing is impractically short because the cavitles overlap; therefore, the $5 \lambda / 4$ spacing is chosen. A long $\mathrm{TM}_{\mathrm{O}} \mathrm{OO}^{-}$mode coupling cavlty connects the modulating cavity to the rest of the side-coupled structure.

The phase-correlated energy spread introduced by this cavity makes it possible to produce a phase compression ratlo of about 3 to 1 before the beam enters the main accelerator.

Flgure 5 shows a section of the proposed $5-\mathrm{MeV}$ Injector linac. The entire section shown is bakedble to $300^{\circ} \mathrm{C}$ and $w 111$ be separated from the beam diagnostic and transport area hy a differentlally pumped section of vacuum lifie. The pressure wlll be maintalned at a level below $10^{-9}$ torr. 6. Emittance measurement of intense bright beams in ally method of measuring the transverse emlttance of a beam, the transport propertles of the beam (or a fraction of the beam passed through an aperture) from one position to another in a beamline are assumed to be known. In some methods, the beam or beamlet simply drifts through a known distance; whereas in others, orie or more transport elements are varled whlle readings of the beam dlameter or froflle are obtalned. The destred 
emittance information is then obtained by invoking the known transfer matrix for the system, either in a single linear equation or in a coupled set of Iinear equations. The assumption implicit in these methods is that the beam-envelope behavior is dominated antirely by the emittance. In other words, space-charge forces can be ignored. As the current in a beam increases, the beam-envelope behavior becomes less dominated by its emittance and more dominated by space-charge forces.

In the rf gun, the current density should inltla ly be quite untform. "or a round, drifting beam of uniform current density, the envelope equation for the rajtus in the absence of external forces [12], is

$$
\frac{d^{2} r}{d z^{2}}-\frac{k}{r}-\frac{c^{2}}{r^{3}}=0 \text {, where } k=\frac{q l}{2 \pi c_{0} M_{0} c^{3}\left(B_{Y}\right)^{3}} \quad \text { (mks unlts) }
$$

and $c$ is the unnormallzed transverse phase space area divided by $\pi$. The ratlo of the space-charge term to the emittance term is proportional to I $r^{2} / \varepsilon^{2}$, from which it is evident that is the beam expands, the space-charge term becomes inore important.

A.A. Garren [13] has developed a dimensionless form of the envelope equation by using the transformations

$$
W=\frac{r}{c} \sqrt{2 K} \text { and } t=\frac{2 K}{c} z \text {. }
$$

The dimensionless envelope equation is then

$$
\frac{d^{2} w}{d t^{2}}-\frac{1}{2 W}-\frac{1}{w^{3}} \cdot 0
$$

The ratlo of the second to the third terms is now $w^{2} / 2$. When $W<\sqrt{2}$. the emfttance term dominates; when $w>\sqrt{2}$, the space-charge term dominates. 
Figure 5 displays Garren's dimensionless parameter $W$ versus the normalized brightness for three beam radil at two low energles. For the brightness regime of interest to FELs, $B_{N}, 10^{10} \mathrm{~A} /\left(\mathrm{m}^{2} \cdot \mathrm{rad}^{2}\right)$, the beams are space-charge dominated unless they are focused to a waist of about $0.1-\mathrm{mm}$ radius. For beams with $W$ of approximately $\sqrt{2}$, it would be possible to measure the emittance of the whole beam if the envelope equation vere used to compute the beam-envelope evolution from one measurement station to another. Therefore, for very bright beams with high peak currents, it is exceedingly difficult to measure the emittance of the whole beam.

On the other hand. for low average-power beams, the pepper-pot method remains a feastble measurement technique. The feasioility lies in the way the parameter $W$ scales with beamlet radius. For a beamlet of radius $r_{0}$ at the center of the beam of radius $r_{\text {tot }}$, the parameter $w_{b}$ is related to $w_{\text {tot }}$ for the whole beam by the equation $w_{b}=w_{\text {tot }} \pi r_{0} /\left(4 r_{\text {tut }}\right)$. in which it is assumed that the current density is uniform. In essence, the pepper-pot method is feastble for high-current beams tecause the spaci charge influence on the beam envelope evolution is reduced whlle the beam orightriess is conserved in the beamlet.

7. Positive ion dynamics in an rf gun cavity

As the electron bunch from the photocathode traverses the rf gun cavity, the bunih : vill lonize some of the residual gas molecules in the cavity. The princlpal censtltuenr of the residual gas is molecular hydrogen, with lesser amounts of $\mathrm{CO}$ and $\mathrm{H}_{2} \mathrm{O}$. Because the cross sections for lonization by electron impact peak at $\% 0 \mathrm{eV}$ for $\mathrm{H}_{2}$ and at $100 \mathrm{eV}$ for $\mathrm{CO}$, the majortty of the lons are created at distances less than $30 \mu \mathrm{m}$ from the photocathode, depending on the phase of electron emission. In a $d c$ fleld of $200 \mathrm{kV} / \mathrm{cm}$, the lons would be created within $5 \mu \mathrm{m}$ of the 
photocathode, and their energles will be equal to the electron energles at the time of Ionization. For a I-A average electron current in a field of $15 \mathrm{MV} / \mathrm{m}$, the $\mathrm{H}_{2}^{+}$ion current is estimated to be $14 \mathrm{pA}$ for a partial pressure of $10^{-9}$ torr. The average impact energy on the photocathode is $440 \mathrm{eV}$.

Because the lon and electron energles of interest are all less than about $1 \mathrm{keV}$, nonrelativistic equations of motion suffice. In an rf field $\tilde{E}-\varepsilon_{0} \cos \phi$. the ion displacement following its creation at $\phi=\phi_{c}$ at position $x_{c}$ is

$x=-Q \frac{\varepsilon_{0}}{M_{\omega}{ }^{2}}\left(\cos \phi+\sin \phi_{c}-\cos \phi_{c}-\phi_{c} \sin \phi_{c}\right)+x_{c}$

where $\phi=\omega t$. The lon motion is a linear drlft with a superimposed sinusoldal motion. The direction of the difft depends on the sign of the creation angle $\phi_{C}$. If $\phi_{c}>0$, the lons orift in the same direction as the rapldly accelerated electrons: If $\phi_{c}<0$, the ions drift backward toward the cathode.

Light lons, like $\mathrm{H}_{2}^{+}$and $\mathrm{H}_{1}^{+}$wlll strlke the cathode in the same rf cycle in which they were produced. Detailed calculations have been made of the $\mathrm{H}_{2}^{+}$lon current impacting the cathode and of the average impact energy. both of which are a function of the creation phase. Figures $7 \mathrm{a}$ and $7 \mathrm{~b}$ give the results for an average electron beam current of $1-A$ in a partlal pressure of $10^{-9}$ torr for $\mathrm{H}_{2}$ in a peak rf fleld of $30 \mathrm{MV} / \mathrm{m}$. For an electron starting phase of $-30^{\circ}$. the average Impact energy for $\mathrm{H}_{2}^{+}$is $350 \mathrm{eV}$ and the current is $7 \mathrm{ph}$. The corresponding results are $440 \mathrm{eV}$, $0.03 \mathrm{pA}$ for $\mathrm{H}^{+}$and $17 \mathrm{eV}, 0.22 \mathrm{pA}$ for $\mathrm{CO}$ (at $10^{-11}$ torr). 


\section{Conclusion}

The prospects are good for producing an improved injector delivering an electron-bunch train tc an FEL rf linac. Important processes involved, such as the production or high peak currents and temporal profiling, have been demonsirated in single-bunch experiments. Further experiments are needed to verify the low emittance and long lifetime of photoemitters in the environment of an rf cavity.

Acknowledgments

The authors are indebted to Stan Schriber for nelpful discussions on f $^{f}$ coupled-cavity structures and to Jerry Watson for discussions on the injector requirements and for continued support of the project.

\section{References}

[1] C. Lejeune and J. Aubert, "Emittance and Brightness: Definitions and Measurements," Applled Charged Particle Optics, A. Septier, Ed., Advances in Electronlcs and Electron Physics. Supp. I3A (Academic Press, New York, 1980).

[2] W. B. Colson arid P. Elleaume, "Electron Dynamlc: In Free-f.lectron Laser Resonator Modes," J. Appl. Phys. B29, 101, (1982).

[3] J. S. Fraser, R. L. Sheffleld, E. R. Gray and G. W. Rodenz, "High-Brightness Photolnfector for Electron Accelerators," Proc. 1985 Partlcle Accel. Conf., IEeE Trans. Nucl. Scl, $\underline{32}$ (5), (1985), In press. 
[4] G. Mavrogenes, W. Gallagher, T. Khoe, and D. Ficht, "High-Charged Plcosecond Pulses with a Double-Gap Subharmonic Buncher," IEEE Trans. Nucl. Sc1. 30 (4), 2989, (1983).

[5] M. B. James, J. E. Clendenin, S. D. Ecklund, R. H. Miller, J. C. Sheppard, C. K. Sinclair, and J. Sodja, "Update on the High-Current Injector for the Stanford LInear Collider." IEEE Trans. Nucl. Sc1. $\underline{30}$ (4), 2992, (1983).

[6] J. L. Adamski, W. J. Gallagher, R. C. Kennedy, D. R. Shoffstall, E. L. Tyson, and A. D. Yeremain, "The Boeing Double Subharmonic Electron Injector-Performance Measurements," Proc. 1985 Particle Accel. Conf.. IEEE Trans. Nucl. Sci, $32(5),(! 985)$, in press.

[7] W. E. Stein, R. W. Warren, J. G. Winston, J. S. Fraser, and L. M. Young, "The Accelerator for the Los A'amos Free-Electron Laser." IEEE J. Quant. Elect. QE-21, July, 1985, in press.

[8] C. Lee, P. Oettlinger, E. Pugh, R. Klinkowsteln, J. Jacob, J. S. Fraser, and R. L. Sheffleld, "Electron Emlssion of over $200 \mathrm{~A} / \mathrm{cm}^{2} \mathrm{From} \mathrm{a}$ Pulsed-Laser Irradlated Photocathode," Proc. 1985 Particle Accel. Conf., IEEE Trans. Nucl. Sc1, 32 (5), (1985), In press.

[9] C. K. Sinclalr and R. H. Miller. "A High Current, Short Pulse, rf Synchronlzed Electron Gun for the Stanford LInear Accelerator." IEEE Trans. Nuc1. Sc1. 28 (3), 2649, (1981). 
[10] M. E. Jones and W. Peter, "Particle-1n-Cell stmulations of The Lasertron," Proc. 1985 Particle Accel. Conf., IEEE Trans Nucl. Scl. $\underline{32}$ (5), (1985), In press.

[11] C. Lee, "Photoelectron Energy Distribution of $\mathrm{Cs}_{3} \mathrm{Sb}$ " J. Appl. Phys. $\underline{54}(8), 4578,(1983)$.

[12] J. D. Lawson, "The Physles of Charged Particle Beams," Coxford University Press, Oxford, Great Britaln, 1977), 194.

[13] A. A. Garren, "Thin Lens Optics With Space Charge," Lawrence Berkeley Laboratory report, UCRL-19313, 1969, unpublished.

[14] H. S. W. Massey and E. H. S. Burhop. "Electronic and Ionlc Impact Phenomena," (Oxford Untversity Press, London, Gieat Britaln, 1952). 


\section{Figure captions}

Fig. 1. Normalized peak brightness for several typlcal subharmonic-buncher systems ir: single-hunch accelerators (Argonne National Laboratory [4], Stanforo Linear Collider [5]) and in pulse traln accelerators (Boeing Aerospace Co. [6], Los A]amos Nationa' Laboratory [7]). The horizontal stralght line represents the theoretical thermal 1 imit for a photocathove with $\mathrm{J}=200 \mathrm{~A} / \mathrm{cm}^{2}$. The objective for a photoemitter infector for FELs is shown in the cross-hatched box. Brightness requirements for two different wavelength FEL oscillators are shown with the emittance requirement noted.

Fig. 2. Proflle cf the llnear-field rf gin cavity. The Inner walls of the cavity (radius $<<\mathrm{Cm}$ ) are given by Eq. (1) with $;=0$ or 0.8 , shown by dashed lines at large radll. The bore radius $151.7 \mathrm{~cm}$.

Fig. 3. The radial electric flelds near the axls of the rf gun cavity (w/thin the cross-hatched area in the insert). The bore radlus is $1.3 \mathrm{~cm}$.

Fig. 4. The radial electric flelds near the axis of a conventional rf accelerator cavlty optlmized for high shunt Impedance (within the cross-hatched area of the Insert [7]).

Flg. 5. A schematic dlagram of a proposed photoemitter injector IInac.

FIg. 6. Garren's [13] dimenslonless parameter $W$ vs beam brightness for a peak current of $200 \mathrm{~A}$. 
Fig. 7. Impact current and tmpact energy as functions of the electron starting phase for a 1-A average electron cuirent in a 1300-MHz if fleld of $30 \mathrm{MV} / \mathrm{m}$ peak amplitude. The resldual gas in the rf cavity Is assumed to be mostly hydrogen at $1 \times 10^{-9}$ torr. 


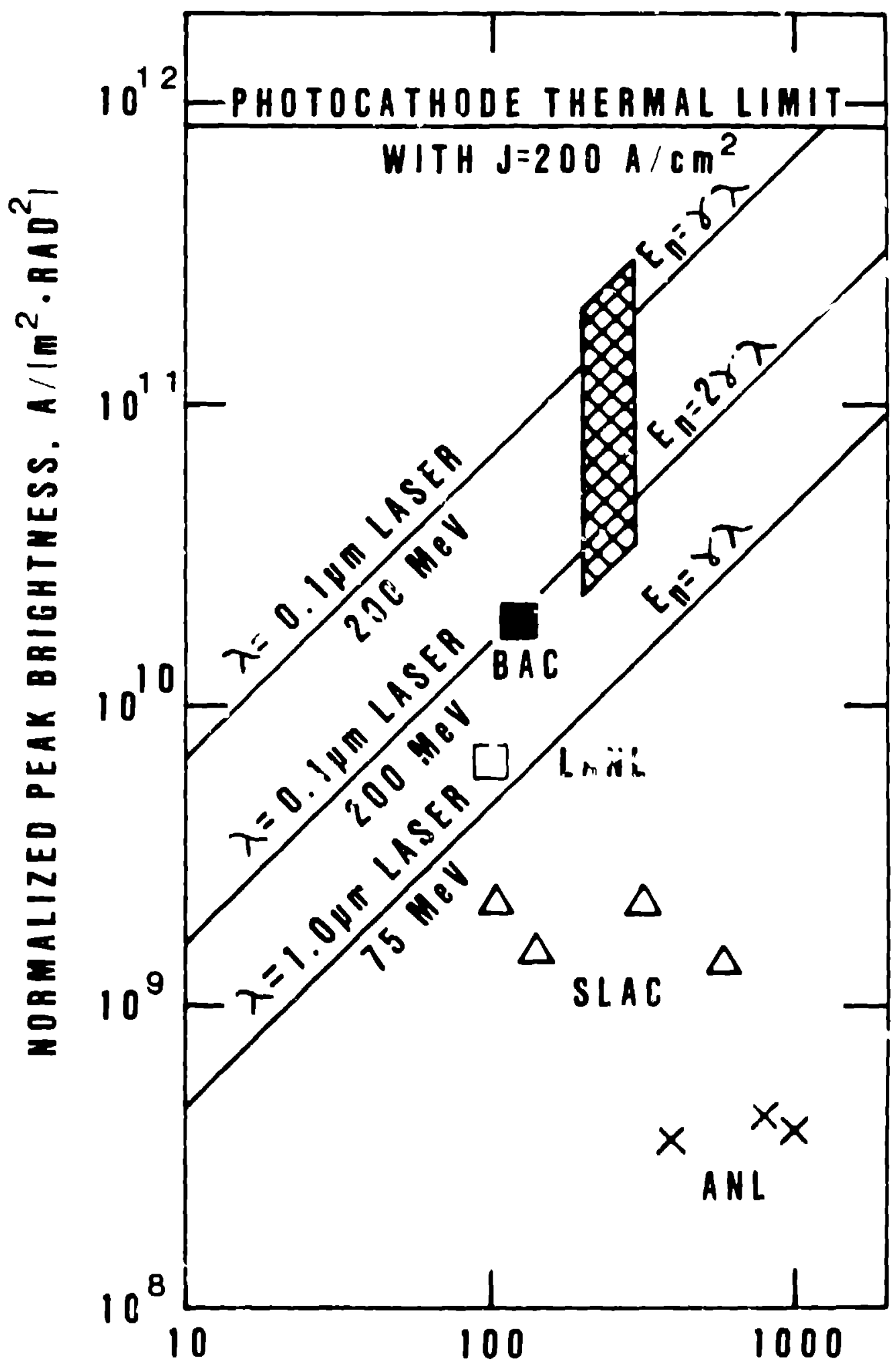

PEAK CURRENT. A 


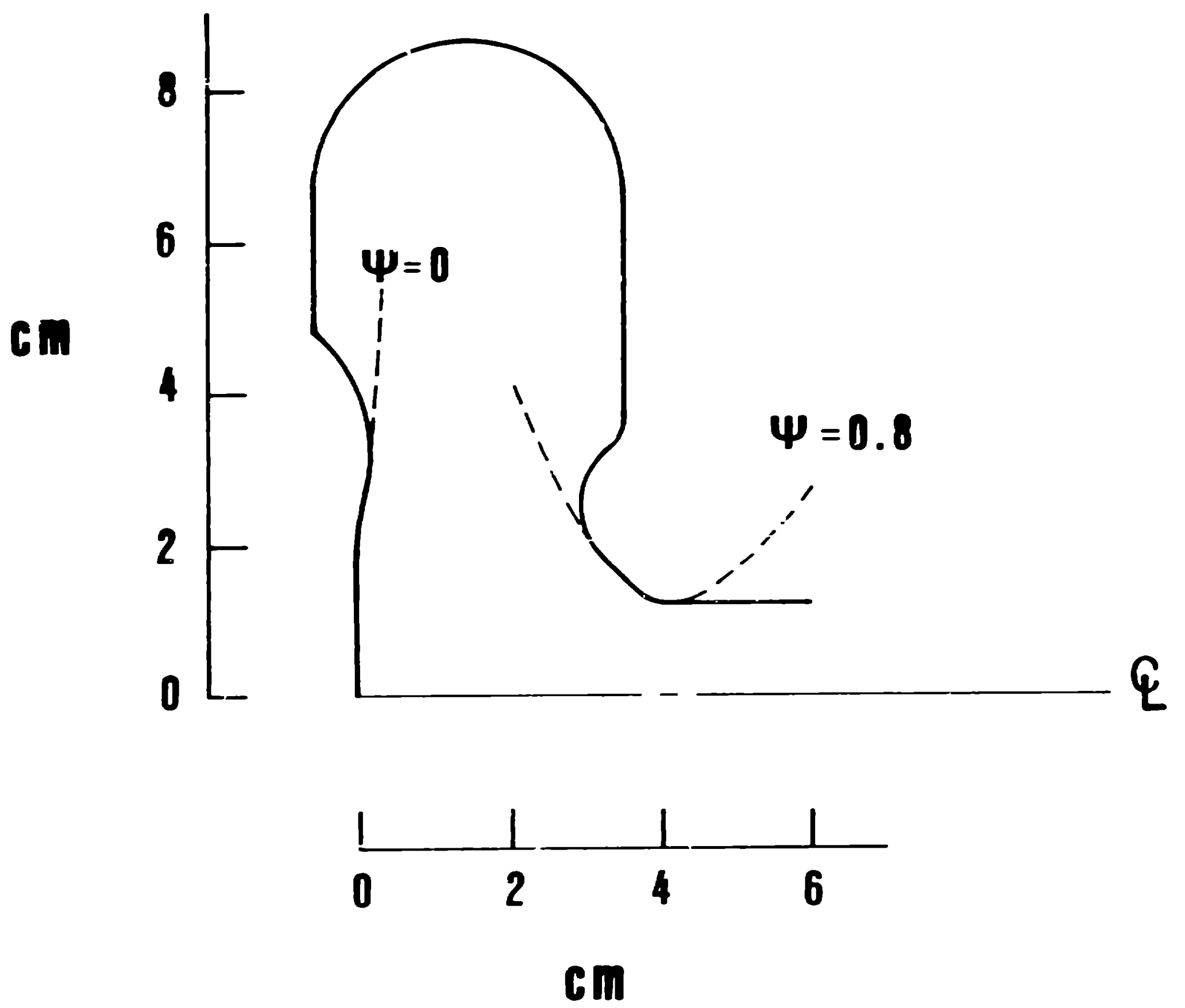




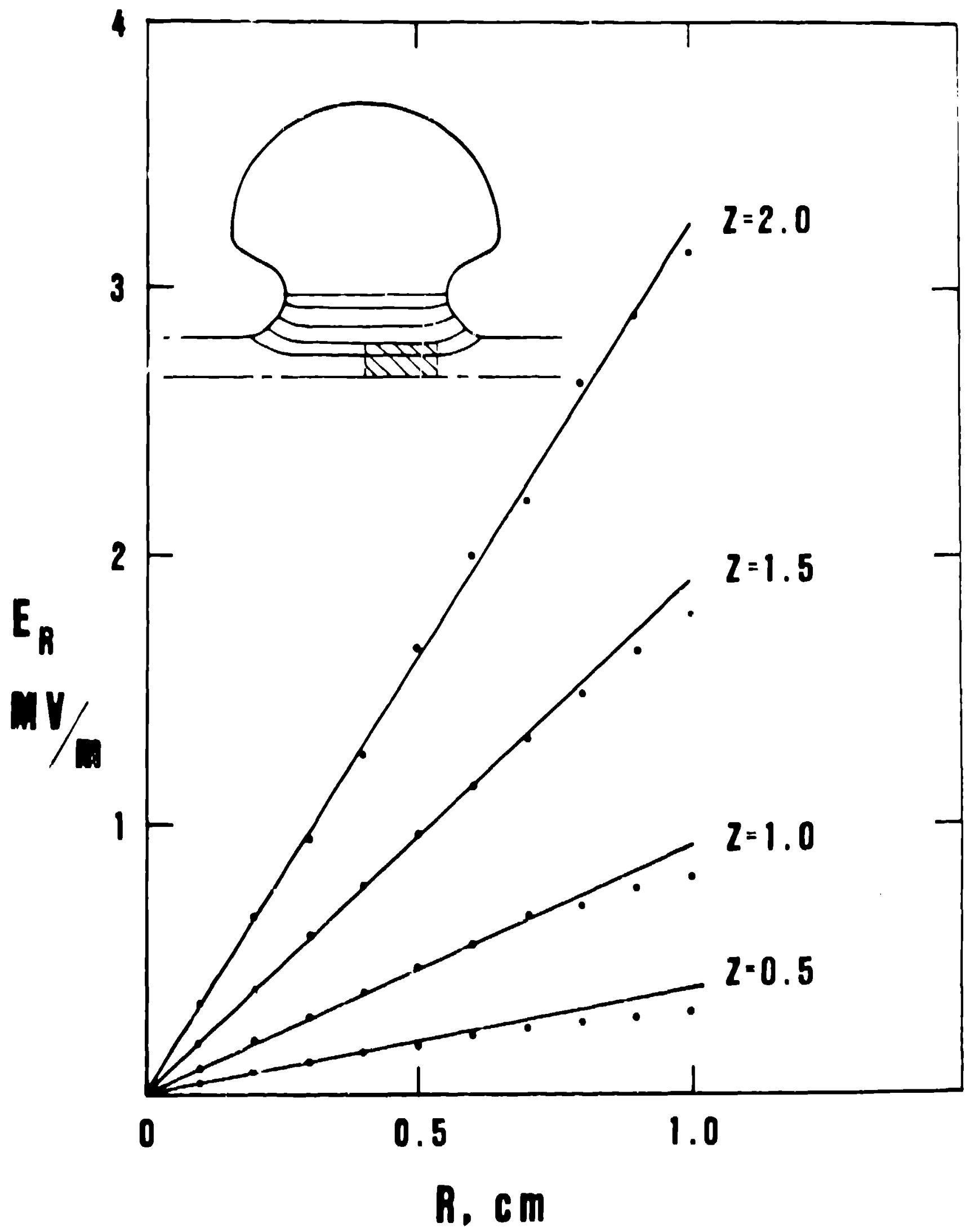

I Iy. 3 


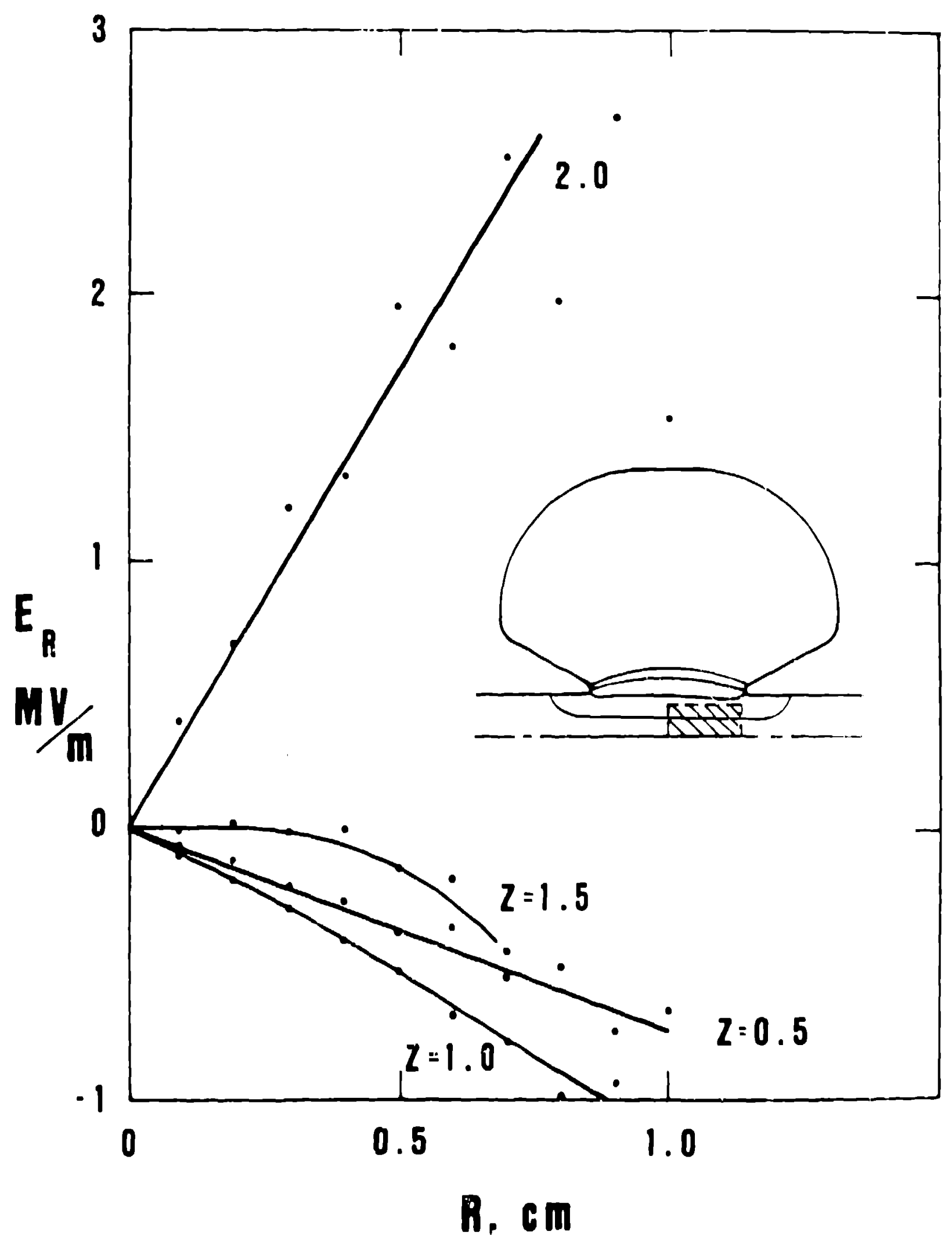

111. 4 


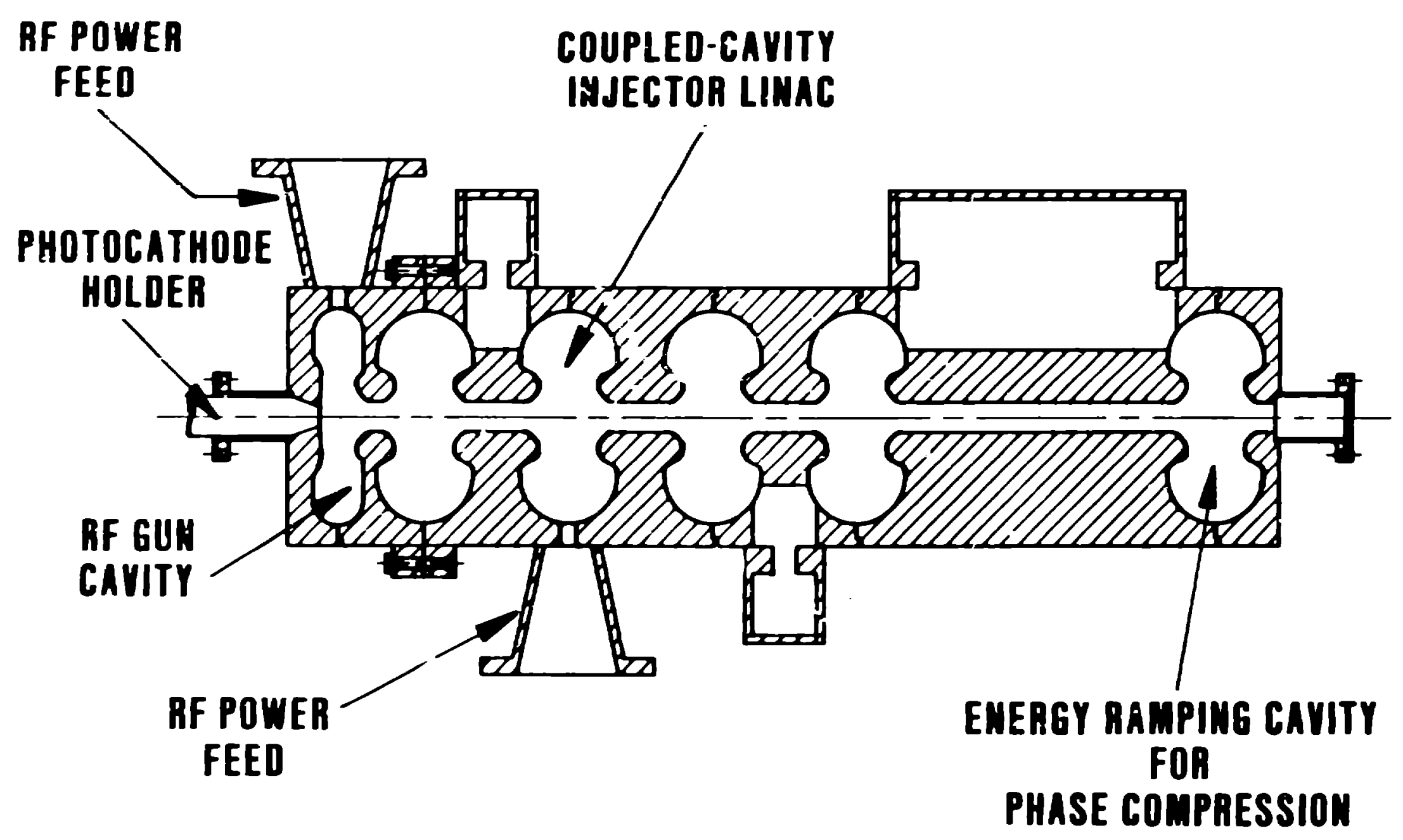

Fig. 5 


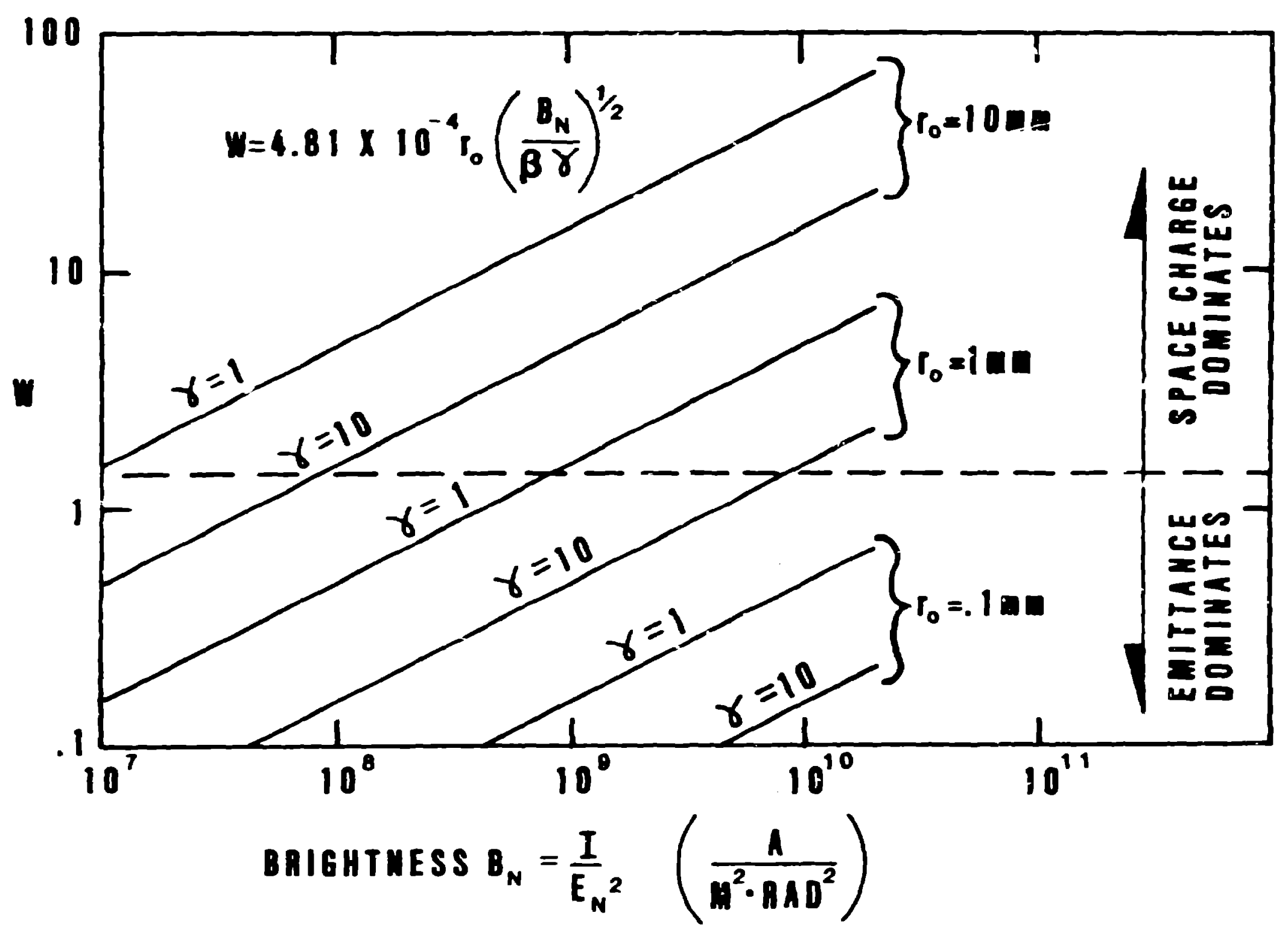

Fig. 6 


\section{H2+ IMPACT ON CATHODE (1E-9 TORB)}
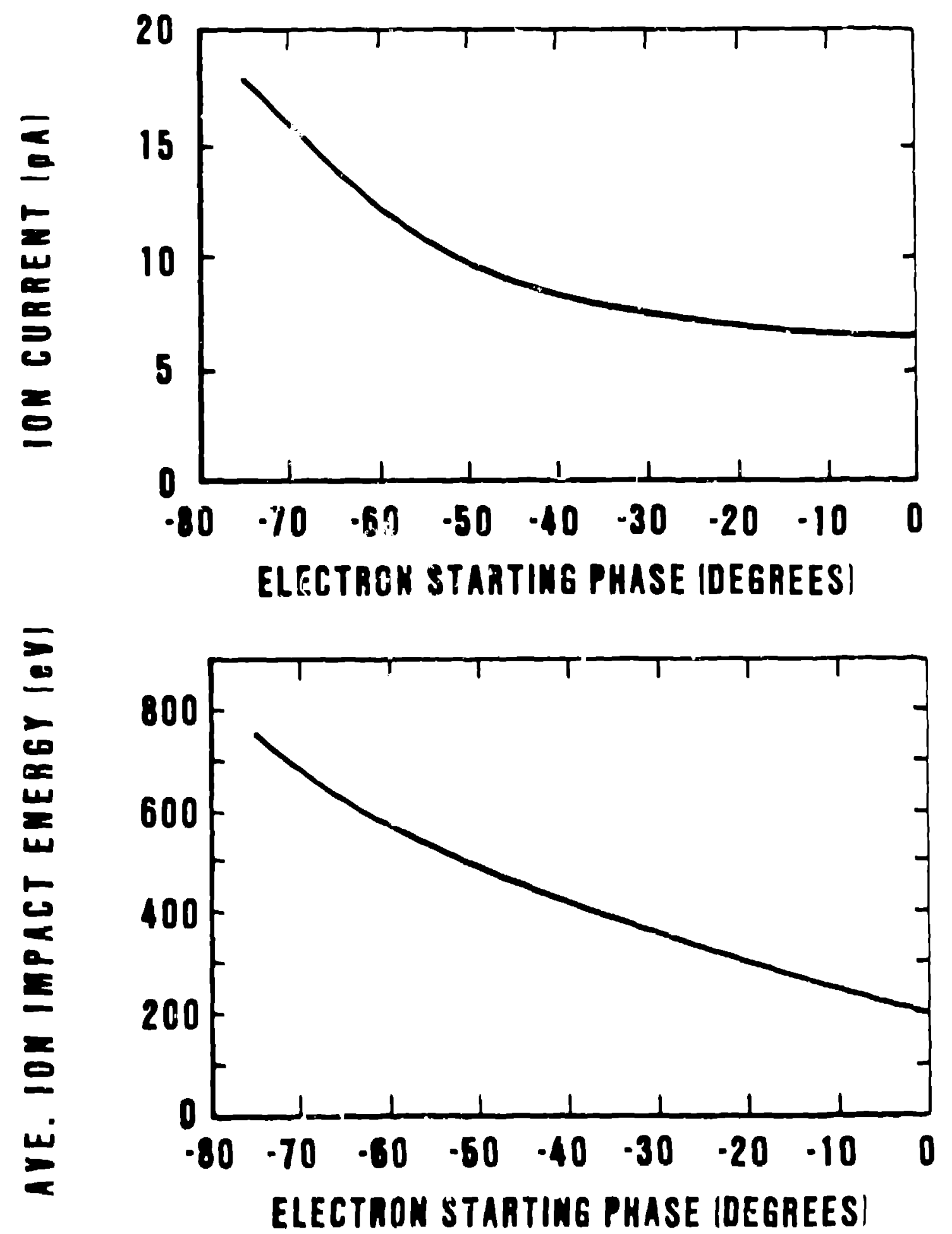